\title{
Interest Rates Targeting of Monetary Policy: An Open Economy SVAR Study of Malaysia
}

\author{
Zulkefly Abdul Karimi* and Bakri Abdul Karim \\ ${ }^{a}$ Faculty of Economics and Management Universiti Kebangsaan Malaysia (UKM) \\ ${ }^{b}$ Faculty of Economics and Business, Universiti Malaysia Sarawak (UNIMAS)
}

\begin{abstract}
This paper examines the implementation of monetary policy during the interest rates targeting in a small-open economy (i.e. Malaysia) by using an open-economy structural VAR (SVAR) study. It tests the effect of foreign shocks upon domestic macroeconomic fluctuations and monetary policy, and examines how effective monetary policy is in influencing macroeconomic variables. The results show that during interest rates targeting, monetary policy plays a significant role in affecting macroeconomics variables. This finding suggests that monetary policy has an important role as a stabilization policy in a smallopen economy.
\end{abstract}

\begin{abstract}
Abstrak: Artikel ini membahas pelaksanaan kebijakan moneter selama suku bunga menargetkan dalam perekonomian kecil terbuka (seperti Malaysia) dengan menggunakan studi VAR struktural perekonomianterbuka (SVAR). Hal ini menguji pengaruh guncangan asing pada fluktuasi makroekonomi domestik dan kebijakan moneter, dan meneliti seberapa efektif kebijakan moneter dalam mempengaruhi variabel makroekonomi. Hasil penelitian menunjukkan bahwa selama penargetan suku bunga, kebijakan moneter memainkan peran penting dalam mempengaruhi variabel makroekonomi. Temuan ini menunjukkan bahwa kebijakan moneter memiliki peran penting sebagai kebijakan stabilisasi dalam perekonomian kecil terbuka.
\end{abstract}

Keywords: interest rates targeting; monetary policy; open-economy; SVAR

* Corresponding author's e-mail: mz@ukm.my or mzkarim72@yahoo.com 


\section{Introduction}

The main question relating to the implementation of monetary policy is either the central bank has to target monetary aggregate or interest rates as an operating target. In Malaysia's experience, the Bank Negara Malaysia (BNM), as the nation's Central Bank has changed its monetary policy strategy from monetary targeting towards interest rate targeting since November 1995. During interest rate targeting, monetary policy operates through short-term interest rates to attain the ultimate target that is a sustainable long-run economic growth, accompanied with price and financial stability. ${ }^{1}$

The aim of this study is to examine empirically on the implementation of monetary policy during interest rates targeting in a small and highly open economy, with special reference to Malaysia. This study uses a non-recursive structural vector autoregressive (SVAR) modelling framework in nine variables, which include three foreign variables, two domestic monetary policy variables, and four macroeconomic variables. By using SVAR study, we can identify the structural economic shocks by imposing a set of restrictions to the contemporaneous interactions of the model variables. For example, after the model has been specified, the impacts of foreign shocks on domestic macroeconomic and monetary policy can be analyzed by using the structural impulse-response function.

The main contributions of this paper have two aspects. First, this study considers the role of the foreign factor in modelling an open-economy SVAR. The previous study of monetary policy effects in Malaysia, for example Azali and Matthews (1999) and Ibrahim (2005) have used a small-scale VAR in a closed-economy, which does not consider the role of foreign variables in their analysis. Therefore, it is essential to examine the foreign shocks effects on macroeconomic fluctuations and monetary policy because the Malaysian economy is relatively small and highly trade-dependent. ${ }^{2}$ Second, this study employs an open economy structural VAR model, which permits an identification of strategies based on economic theory rather than the sometimes questionable assumptions which underlie a traditional recursive VAR. In the Malaysian context, although Tang (2006) has considered recursive VAR in an open-economy, and Ibrahim (2005) has used recursive VAR in a closed-economy, however their identification of structural shocks is inappropriate. Thus, this study provides a novel contribution to the monetary policy

\footnotetext{
${ }^{1}$ During the interest rate targeting, monetary policy in Malaysia can be categorized into three main evolutions. Firstly, from November 1995 up to September 1998, the BNM has introduced a new Base Lending Rate (BLR) framework which takes into account the 3-month interbank rate in the BLR formula. Secondly, since September 1998, the BNM has employed interest rate targeting with a fixed exchange rate, and modified the BLR framework taking into account the Intervention Rate in the determination of BLR formula. At the same time, due to the currency crisis that occurred in the East Asian region, the BNM implemented capital controls to stabilize the economy. Thirdly, since April 2004, the BNM has introduced a new interest rates framework, the Overnight Policy Rate (OPR) to signal the monetary policy stance. During this period, the BNM has gradually liberalized capital control, and has eliminated the pegging with the US dollar since July 2005.

${ }^{2}$ In Malaysia, the degree of economic interdependence or economic openness as measured by the share of exports and imports as a percentage of GDP has increased significantly from 86.88 percent in 1970 to 112.59 percent in 1980 and 146.89 percent in 1990. In fact, since 1999 it has been greater than 200 percent. These statistics indicate that the Malaysian economy is highly dependent, and thus vulnerable to external shocks, for example foreign income shocks from large countries.
} 
analysis in a small-open economy (i.e. Malaysia) by identifying the structural shocks according to the economic theory. The results of the study indicate that monetary policy has a significant role as a stabilization policy during interest rates targeting in stimulating macroeconomic variables, and mitigating the negative effects of the external shock to the domestic economy. Foreign shocks appeared to play a prominent role in influencing domestic macroeconomic and monetary policy variables. There is also no evidence for output puzzle, and exchange rate puzzle. However, there is a price and liquidity puzzle during the interest rates targeting.

The rest of the paper is organized as follows. Section 2 presents a literature review relating to the monetary policy identification scheme in the SVAR literature. Section 3 briefly discusses the research methodology, and Section 4 presents the empirical results by focusing on structural impulse-response function (SIRF). Section 5 summarizes and concludes.

\section{Literature Review}

There are a limited number of studies in small-open economies which examined the effect of the monetary policy shocks by using an open SVAR approach. For example, the most recent SVAR studies of a small-open economy were conducted by Cushman and Zha (1997), Brischetto and Voss (1999), Dungey and Pagan (2000), Parrado (2001), and Buckle et al. (2007). Most of the studies have used block exogeneity restrictions in modelling the international economic linkages to the small-open economy.
Cushman and Zha (1997) and Dungey and Pagan (2000) have imposed two blocks in their structural equation model, which is a block representing the international economy, and a block representing the domestic economy. In modelling SVAR for the Canadian economy, Cushman and Zha (1997) included four international variables, namely the US industrial production, the US consumer prices, the US federal fund rate, and world total commodity export prices. The main identification scheme in their study has three aspects. First, domestic interest rates are assumed to react contemporaneously to foreign interest rates and commodity markets, but not on contemporaneous output. Second, the exchange rate is assumed to respond contemporaneously to all shocks. Third, foreign variables are treated as a separate block, which is block (exogenous) for the domestic (small open) economy. This means that, domestic variables are not allowed to affect foreign variables either contemporaneously or with a lag. The empirical findings stated that Canadian monetary policy responded significantly and contemporaneously with home interest rates, exchange rate, foreign interest rates and foreign price levels. In addition, there is no evidence of interest rates puzzles, ${ }^{3}$ exchange rates puzzles and prices puzzles, and the external shocks become the dominant source of domestic output fluctuations. Monetary policy shocks (an increase in interest rates) has a small but negative effect on output.

In contrast, Dungey and Pagan (2000) included five international variables, namely real US GDP, real US interest rates, the Australian term of trade, ${ }^{4}$ the Dow Jones Index

${ }^{3}$ The interest rates puzzle or output puzzle is a monetary contraction where-by an increase in interest rates is associated with an increase in output level rather than a decrease.

${ }^{4}$ Terms of trade refers to the relative price of exports in terms of imports, and it defined as the ratio of export prices to import prices. 
deflated with the US consumer price index, and real exports. The Australian monetary policy (cash rate) is assumed to follow a standard Taylor-rule, which is response contemporaneously with Australian gross national expenditure and inflation. The domestic variables are assumed not to affect foreign variables either contemporaneously or with a lag. The main findings indicated that overseas factors are generally a substantial contributor to domestic activity, and domestic monetary policy contributes to stabilizing economic activity, but the effect is not large.

In the Malaysian context, there have been few studies relating to the effect of monetary policy shocks on economic activities in the existing literature. For example, Azali and Matthews (1999) have employed Bernanke's (1986) contemporaneous structural VAR approach (six variables in a closedeconomy) in investigating the relationship between money-income and credit-income during the pre- and the post-liberalization eras. They found that, during the pre-liberalization period, the bank credit shock had more impact compared with the money shock in explaining output variability. In contrast, after the post-liberalization period, money, as well as credit innovations, were significant in explaining output shocks. In short, aggregate demand was significantly influenced by credit innovation during pre-liberalization, while money innovation played an important role during post-liberalization in explaining output variability.

Another study by Ibrahim (2005) used recursive VAR identification in a closed economy in examining the sectoral effect of a monetary policy shock. His results supported the real effect of monetary policy shocks. For example, it was seen that real output declined during monetary tightening (positive shocks of interest rates). In fact, some sectors such as manufacturing, construction, finance, insurance, real estate, and business services seem to decline more than aggregate production in responding to the interest rates shocks. In short, those sectors that are very heavily dependent on bank loans are more sensitive to monetary policy shocks. In comparison, a recent study by Tang (2006) has examined the relative importance of the monetary policy transmission mechanism channel (interest rates, credit, asset price, and exchange rate channel) by using 12 variables in an open-economy VAR model. The variables are four foreign variables (foreign block), and eight domestic variables (domestic block), which is estimated by using a recursive VAR identification scheme. The foreign block is assumed not completely exogenous to the domestic block, in which the domestic variables are allowed to affect the foreign variables in a lag but not contemporaneously. His findings conclude that the interest rates channel plays a pivotal role in influencing output and inflation. In addition, the asset price channel is also relevant for explaining output variability, but for inflation, the exchange rate channel is more relevant than the asset price channel.

\section{Methods}

\section{Data and Variables Description}

All data are at a monthly frequency spanning from November 1995 until May 2009 (during interest rates targeting regime), and collected from the IMF's International Financial Statistic (IFS), except for asset price, where the data are collected from Thompson Data stream. All variables are transformed into logs except for FFR, INF and IBOR, which are stated in percentage points. Spe- 
cifically, the endogenous variables included in the VAR are;

Oil Price (LOIL). It refers to the log of world oil prices (US \$ per barrel). The world oil price is an indicator of adverse supply shocks (inflationary and contractionary) to the Malaysian economy. Therefore, it is expected that positive shocks in the world oil prices will increase the cost of production, and subsequently will trigger cost-push inflation and reduced investment spending, subsequently leading to a contraction in economic activity.

Foreign Income (IPIUS). This study uses the US Industrial Production Index as a proxy for foreign income. The selection of US income as a proxy for foreign income is reasonable since the US is the major trading partner of Malaysia. For instance, on average, from 1997 to 2008, exports to the US have constituted 20 percent of the total Malaysian exports, most of which have been concentrated on manufacturing products such as electrical and electronic goods and textiles, clothing and footwear. ${ }^{5}$

Foreign Monetary Policy (FFR). The Federal Fund Rate of the US is used as a proxy for foreign monetary policy. FFR is also an appropriate indicator in analyzing the effect of foreign monetary policy on a small-open economy given that the US is a large economy and has a powerful impact in the international arena. Any changes in the FFR will signal the condition of the US economy, and subsequently is expected to transmit to the mon- etary policy stance and macroeconomic fluctuations in a small-open country economy.

Domestic Income (IPIM). Domestic income is a target variable, which is proxied by the Malaysian Industrial Production Index. In Malaysia, the Industrial Production Index (IPI) is a good proxy for output because it comprises the three main indices in the economy; the manufacturing index (weighted $70.7 \%$ ), mining index (weighted $23.4 \%$ ), and electricity Index (weighted 6.0\%).

Inflation (INF). Another target variable is the inflation rate (INF) which is calculated from the changes in the Consumer Price Indices $(\mathrm{CPI})^{6}$. The inclusion of INF in the model is reasonable given that the BNM has been targeting the inflation rate as an objective since 1990.

Monetary Aggregate (LM). The narrow monetary aggregate M1 is also considered as a monetary policy variable because M1 is more liquid, and thus demanded for transactions purposes. The inclusion of M1 is also consistent with previous studies, for example Tang (2006) who stated that M1 is the best candidate for a monetary aggregate because it is relatively stable and more liquid compared to the broad monetary aggregate.

Interest Rates (IBOR). The interbank overnight rate (IBOR) is also a good candidate for a monetary policy variable because the BNM has directly influenced the interbank rate through its intervention in the money market (Domac, 1999). In fact, since April 2004, the BNM has introduced a new mon-

\footnotetext{
${ }^{5}$ This figure is based on the author's calculation from the Bank Negara Malaysia, Monthly Statistical Bulletin. Besides the US, the other Malaysian major trading partners are ASEAN countries (particularly Singapore), Japan and the European Union. For instance, in 2008 the US, Singapore, Japan and the European Union have absorbed 52.23 percent of the total Malaysian exports.
}

${ }^{6}$ The standard formula to compute the inflation rate is $\frac{C P I_{t}-C P I}{C P I} t-1=100$ 
etary policy framework, namely the Overnight Policy Rate (OPR) to signal the monetary policy stance.

Kuala Lumpur Composite Index (KLCI). Kuala Lumpur Composite Indices (KLCI) is also important for analyzing the effect of the monetary policy on the asset prices, and can examine how the economic activity responds to the stock market development. ${ }^{7}$ For instance, an easing of monetary policy through increasing the amount of the money supply (or reduction in interest rates) leads to an increase in the stock market (asset price), and subsequently will stimulate the economic activity via two channels - a wealth effect and a Tobin's-q effect.

Nominal Effective Exchange Rate (NEER). Besides asset prices, the role of the exchange rate is also important given that Malaysia has a highly trade-dependent economy, and any changes in exchange rate will significantly affect the external sectors, particularly export and import.

In addition to the endogenous variables, the model also includes two dummy variables for breaks in the intercept, which coincide with major economic events. Specifically, the events are: the period in which the Ringgit was pegged to the US dollar, and the Asian financial crisis. It is assumed these two events only influence variables in the domestic block rather than the foreign block. In addition, the seasonal dummy has also considered for all endogenous variables.

\section{Time Series Properties}

Much of the SVAR literature in monetary policy has ignored possible nonstationarity of the variables in the VAR model. ${ }^{8}$ However, ignoring nonstationarity in the VAR system is inappropriate because only stationary variables return to the long-run mean after a shock. In this study, the Augmented Dickey-Fuller (ADF) test was employed to investigate the presence of unit roots in the data. After testing for unit roots, the optimum lag in the VAR model is chosen by using the Akaike information criteria (AIC).

\section{Malaysian Structural VAR Modelling}

The endogenous variables are divided into two blocks; namely foreign and domestic. The foreign block includes the world oil price, foreign income, and a foreign monetary policy measure. The domestic block includes target variables (domestic output and inflation), policy variables (monetary aggregate and interest rates), and two other variables namely asset prices and the exchange rate. It is assumed that a small-open economy like Malaysia is described by a structural form representation. The dynamic relationship of the system of equation in the structural model can be written as follows;

$$
A_{0} Y_{t}=\Gamma_{0} D_{0}+A(L) Y_{t}+\varepsilon_{t}
$$

\footnotetext{
${ }^{7}$ An excellent literature survey about the effect of monetary policy on stock prices can be found in Sellin (2001).

${ }^{8}$ Ramaswamy and Sloek (1997) have discussed extensively whether the VAR model should be estimated in level, difference or in vector error correction model (VECM).
} 
Where,

$A_{0} \quad$ is an invertible square matrix of coefficients relating to the structural contemporaneous interaction between the variables in the system,

$Y_{t} \quad$ is a $(9 \times 1)$ matrix that is the vector of system variables or [ $\triangle$ LOIL $\triangle$ LIPIUS FFR $\triangle$ LIPIM INF VLM IBOR $\triangle$ LNEER $\triangle$ LKLCI],

$\mathrm{D}_{0} \quad$ is a vector of deterministic variables (constant, trend and dummy variables),

$\mathrm{A}(\mathrm{L})$ is a $k^{\text {th }}$ order matrix polynomial in the lag operator $\mathrm{L}\left[\mathrm{A}(\mathrm{L})=\mathrm{A}_{1} \mathrm{~L}-\mathrm{A}_{2} \mathrm{~L}^{2}-\ldots-\right.$ $\left.\mathrm{A}_{\mathrm{k}} \mathrm{L}^{\mathrm{k}}\right]$,

$\varepsilon_{t}=\left[\varepsilon_{t}^{\Delta \mathrm{LOIL}} \varepsilon_{\mathrm{t}}^{\Delta \mathrm{LIPIUS}} \varepsilon_{\mathrm{t}}^{\Delta \mathrm{FFR}} \varepsilon_{\mathrm{t}}^{\Delta \mathrm{LIPIM}} \varepsilon_{\mathrm{t}}^{\Delta \mathrm{INF}} \varepsilon_{\mathrm{t}}^{\Delta \mathrm{LM}}\right.$ $\left.\varepsilon_{t}^{\Delta I B O R} \varepsilon_{t}^{\Delta L N E E R} \varepsilon_{t}^{\Delta L K L C l}\right] \varepsilon_{t}^{\Delta L O I L}$ is the vector of structural shocks which satisfies the conditions that $\mathrm{E}\left(\varepsilon_{\mathrm{t}}\right)=0, \mathrm{E}\left(\varepsilon_{\mathrm{t}} \varepsilon_{\mathrm{s}}\right)=$ $\Omega_{\varepsilon}=\mathrm{I}$ (identity matrix) for all $\mathrm{t}=\mathrm{s}$

Equation (1) cannot be directly estimated to derive the true value of $A_{0}, A(L)$ and $\varepsilon_{t}$. However, equation (1) can be estimated by transforming to the reduced form representation as follows;

$$
\mathrm{Y}_{\mathrm{t}}=\mathrm{A}_{0}^{-1} \Gamma_{0} \mathrm{D}_{0}+\mathrm{A}_{0}^{-1} \mathrm{~A}(\mathrm{~L}) \mathrm{Y}_{\mathrm{t}}+\mathrm{A}_{0}^{-1} \varepsilon_{\mathrm{t}} \cdots
$$

or

$$
\mathrm{Y}_{\mathrm{t}}=\mathrm{A}_{0}^{-1} \Pi_{0} \mathrm{D}_{0}+\Pi_{1}(\mathrm{~L}) \mathrm{Y}_{\mathrm{t}}+\mu_{\mathrm{t}}
$$

Where, $\Pi_{0}=\mathrm{A}_{0}^{-1} \Gamma_{0}, \Pi_{1}=\mathrm{A}_{0}^{-1} \mathrm{~A}(\mathrm{~L}), \mu_{\mathrm{t}}=\mathrm{A}_{0}^{-1}$ and $E\left(\mu_{t} \mu_{t}^{\prime}\right)=A_{0}^{-1} \Omega A_{0}^{-1^{\prime}}=\Sigma$

The solution to the SVAR system can be generated by recovering the relationship between the reduced-form disturbances $\left(\mu_{t}\right)$, and the underlying structural shocks $\left(\varepsilon_{t}\right)$. This relationship can be estimated by using the Equation (3), which is $\mu_{t}=A_{0}{ }^{-1} \varepsilon_{t}$ or $A_{0} u_{t}=$ $\varepsilon_{t}$ using the maximum likelihood estimates. In matrix form, this relationship can be represented as follows;

$\left[\begin{array}{ccccccccc}1 & 0 & 0 & 0 & 0 & 0 & 0 & 0 & 0 \\ a_{21}^{0} & 1 & 0 & 0 & 0 & 0 & 0 & 0 & 0 \\ a_{31}^{0} & a_{32}^{0} & 1 & 0 & 0 & 0 & 0 & 0 & 0 \\ a_{41}^{0} & 0 & 0 & 1 & 0 & 0 & 0 & 0 & 0 \\ a_{51}^{0} & 0 & 0 & a_{54}^{0} & 1 & 0 & 0 & 0 & 0 \\ a_{61}^{0} & a_{62}^{0} & a_{63}^{0} & a_{64}^{0} & a_{65}^{0} & 1 & 0 & 0 & 0 \\ a_{71}^{0} & a_{72}^{0} & a_{73}^{0} & a_{74}^{0} & a_{75}^{0} & a_{76}^{0} & 1 & 0 & 0 \\ a_{81}^{0} & a_{82}^{0} & a_{83}^{0} & a_{84}^{0} & a_{85}^{0} & a_{86}^{0} & a_{87}^{0} & 1 & 0 \\ a_{91}^{0} & a_{92}^{0} & a_{93}^{0} & a_{94}^{0} & a_{95}^{0} & a_{96}^{0} & a_{97}^{0} & a_{98}^{0} & 1\end{array}\right]\left[\begin{array}{c}\mu_{t}^{\Delta L O I L} \\ \mu_{t}^{\Delta L I P I U S} \\ \mu_{t}^{F F R} \\ \mu_{t}^{\Delta L I P I M} \\ \mu_{t}^{I N F} \\ \mu_{t}^{I B O R} \\ u_{t}^{\Delta L M} \\ \mu_{t}^{\Delta L N E E R} \\ \mu_{t}^{\Delta L K L C I}\end{array}\right]=\left[\begin{array}{c}\varepsilon_{t}^{\Delta L O I L} \\ \varepsilon_{t}^{\Delta L I P I U S} \\ \varepsilon_{t}^{F F R} \\ \varepsilon_{t}^{\Delta L I P I M} \\ \varepsilon_{t}^{I N F} \\ \varepsilon_{t}^{I B O R} \\ \varepsilon_{t}^{\Delta L M} \\ \varepsilon_{t}^{\Delta L N E E R} \\ \varepsilon_{t}^{\Delta L K L C I}\end{array}\right]$

In identifying the structural VAR model, this study employed the SVAR-A model proposed by Amisano and Giannini (1996). Enough restrictions have to be imposed on matrix $A_{0}$. According to the order condition, for the system to be just identified or exactly identified, it requires $\mathrm{K}(\mathrm{K}-1) / 2=9(8) / 2=36$ zero restrictions on the contemporaneous matrix $A_{0}$. However, since the contemporaneous matrix $A_{0}$ in Equation (4) has 40 zero restrictions, the SVAR model is over-identified.

In addition to the endogenous variables, the model also includes two dummy variables for breaks in the intercept, which coincide with major economic events. Specifically, the events are: the period in which the Ringgit was pegged to the US dollar, and the Asian financial crisis. It is assumed these two events only influence variables in the domestic block rather than the foreign block. In addition, the seasonal dummy has also considered for all endogenous variables. By considering the two dummy variables and seasonal dummy, it is believed that the structural of the impulse response function will not change and be stable during the sample of the study. Therefore, it is not necessary to split the sample 
according to pre-crisis and post crisis period. In fact, by splitting the sample, it will decrease the number of observations across the subsample, and also will lose the degree of freedom in VAR analysis after considering the optimum lag. Thus, for that reason this study will not split the sample size. ${ }^{9}$

\section{Identification Scheme}

The variables in foreign blocks have been assumed to be completely exogenous to the domestic blocks. It is common to identify that the foreign variables do not respond contemporaneously or with a lag to the movement in the domestic variables in a small-open country. Specifically, the world oil price is a structural disturbance or exogenous variable that is uncorrelated with other contemporaneous shocks. Meanwhile, the US income and Federal Fund Rate (FFR) can influence world oil price in a lag. The US income is assumed to respond contemporaneously with the world oil price and all foreign variables lag. The US monetary policy (Jensen and Mercer 2002) is assumed to respond contemporaneously to the innovations in world oil price and the US income and all foreign variables lag. The FFR reacts positively to the world oil price in minimizing the inflationary pressure due to the positive shocks of world oil prices. This assumption is also consistent with prior studies, for example, Hamilton (1996) and Bernanke et al. (1997) who found that oil price movements have a significant forecast power for the stance of monetary policy in the US economy. In contrast, FFR responds negatively with the US income in minimizing the output gap.
Domestic output growth has been assumed to respond contemporaneously only to the world oil price shocks, and respond in the lags to all endogenous variables. Domestic output growth reacts positively to the current growth of world oil prices. This assumption is reasonable given that Malaysia is a net exporter of oil. However, in the long run, the relationship between oil price and output is expected to be negative because an increase in the world oil price will increase the cost of production, whereas the firms will respond by cutting the level of production or investment. In addition, it is assumed that Malaysian output does not respond contemporaneously with other variables in the system. For instance, the monetary policy variable, that is, monetary aggregate and interest rates, cannot influence output contemporaneously. The main plausible justification for this assumption is that firms do not change their output and prices instantaneously in responding to the monetary policy signal within a month, due to the inertia, adjustment costs and planning delay, but they will respond immediately to the current oil prices following their markup rule (Kim and Roubini 2000). This type of restriction is also imposed by Bernanke and Blinder (1992), and Bernanke and Mihov (1998).

Domestic inflation has been assumed to respond contemporaneously to the innovations in oil prices and domestic output. The positive innovation in oil prices and domestic output will spontaneously accelerate the domestic price level. However, other variables in the system cannot influence domestic inflation spontaneously because inflation

\footnotetext{
${ }^{9}$ In their study about foreign shocks and monetary policy in Malaysia, Zaidi and Fisher (2010) also did not split the sample of observation into subsamples. They argues that incorporating dummy variables to represent major events in Malaysian Economy, the shocks (Impulse Response Function) in VAR model will be more stable than splitting the sample observation.
} 
is a slow-moving variable. However, all endogenous variables are assumed to affect the inflation rate in the lags.

In market economies, the use of the interest rates as a major instrument of monetary policy does not imply that it can ignore the role of the money supply. This is because the interest rates are determined in financial markets. For example, if the monetary authority wants to lower the interest rates but do not support this aim with a required increase in the money supply, it would find that the market interest rates would deviate from its desired level. As a result, the intended effects on expenditure will not be achieved. Therefore, an interest rate policy must be accompanied by an appropriate money supply (Handa 2009). For that reason, this study will consider two types of monetary policy shocks, namely, money supply and interest rates.

During interest rates targeting, it is assumed that the monetary authority sets the interest rates after observing the current value of domestic variables ie. domestic output and inflation, and all foreign variables, but not the current value of other variables. The inclusion of output and inflation in the monetary policy reaction function is reasonable given that the central bank can observe data from these variables on a monthly basis. The inclusion of foreign monetary policy in the domestic monetary policy reaction function is reasonable given that the Malaysian economy is highly dependent on the US economy. Therefore, it is reasonable to assume that the BNM will respond positively to the US monetary policy in minimizing the capital outflow as well as stabilizing the domestic currency. The justification of the monetary policy reaction function is also consistent with previ- ous studies, for example, Kim and Roubini (2000), Cushman and Zha (1997), and Sim and Zha (2005).

It is assumed that the monetary authority (the BNM) sets the money supply after observing the current level of all foreign variables, domestic output growth, inflation, and interest rates. This is reasonable given that the monetary authority can observe the data on a monthly basis and choose the amount of money supply to offset any negative effect resulting from foreign shocks, domestic aggregate demand and inflation shocks to the domestic economy.

The exchange rate is assumed to respond contemporaneously with all foreign and all domestic variables (except stock prices). In contrast, the asset price is assumed to respond contemporaneously to all foreign and all domestic variables. This assumption is reasonable given that the exchange rate and stock market are the fast-moving variables in the system. The asset price is assumed to respond contemporaneously to the exchange rate because any changes to the exchange rate will influence international capital mobility, which in turn affects the stock market. For instance, an appreciation in domestic currency makes domestic assets more expensive to the international investors, and therefore decreases the demand for domestic asset, subsequently leading to a decline in the asset price.

\section{Empirical Results}

\section{Preliminary Analysis}

Table 1 reports the result of the unit root test by using the Augmented DickeyFuller test. As can be seen, only three vari- 
ables, which are the FFR, inflation (INF), and interbank overnight rate (IBOR) are stationary at level form at least at 10 percent significance level; meanwhile other variables are stationary in first difference form. ${ }^{10}$ The optimum lag in the VAR system is four according to the Akaike information criterion (AIC). Since the baseline SVAR model is over-identified, we need to test the validity of the overidentification restrictions. The value of $\chi^{2}$ (with four degrees of freedom) is 7.97 and the probability is 0.11 , which indicates that the over-identification restrictions are valid. ${ }^{11}$

\section{Structural Impulse Response Function (SIRF)}

Appendix 1-Appendix 3 illustrates the structural impulse response functions of the endogenous variables in this study. The main focus is to analyze the foreign shock effects on domestic variables (monetary policy and macroeconomic variables), the effect of domestic monetary policy shocks (monetary aggregate and interest rates) on domestic macroeconomics variables, and how effective is monetary policy in mitigating the negative

Table 1. Unit Root Test: Augmented Dickey Fuller (ADF)

\begin{tabular}{lcccc}
\hline Variables & \multicolumn{2}{c}{ Level Form } & \multicolumn{2}{c}{ First Difference } \\
\cline { 2 - 6 } & $\begin{array}{c}\text { Constant and } \\
\text { No Trend }\end{array}$ & $\begin{array}{c}\text { Constant and } \\
\text { Trend }\end{array}$ & $\begin{array}{c}\text { Constant and } \\
\text { No Trend }\end{array}$ & $\begin{array}{c}\text { Constant and } \\
\text { Trend }\end{array}$ \\
\hline LOIL & $-2.009(2)$ & $-2.477(2)$ & $-11.578^{* * *}(1)$ & $-11.606^{* * *}(1)$ \\
LIPIUS & $-1.842(12)$ & $-1.870(12)$ & $-6.531^{* * *}(10)$ & $-6.593^{* * *}(10)$ \\
FFR & $-3.336^{* * *}(12)$ & $-3.896^{* * *}(12)$ & $-4.791^{* *}(12)$ & $-4.822^{* * *}(12)$ \\
LIPIM & $-1.571(12)$ & $-1.694(12)$ & $-4.153^{* * *}(12)$ & $-4.323^{* * *}(12)$ \\
INF & $-3.446^{* * *}(10)$ & $-3.365^{* * *}(10)$ & $-6.816^{* * *}(12)$ & $-6.935^{* * *}(12)$ \\
LM1 & $0.433(10)$ & $-1.802(9)$ & $-3.054^{* * *}(12)$ & $-3.077^{* * *}(12)$ \\
IBOR & $-2.846^{*}(6)$ & $-3.214^{*}(7)$ & $-7.972^{* * *}(7)$ & $-7.961^{* * *}(7)$ \\
LNEER & $-1.373(3)$ & $-2.817(3)$ & $-8.144^{* * *}(7)$ & $-8.592^{* * *}(2)$ \\
LKLCI & $-2.008(3)$ & $-2.913(3)$ & $-10.719^{* * *}(2)$ & $-10.711^{* * *}(2)$ \\
\hline Note* & $(3)$ & & & $(3)$
\end{tabular}

Note:*** Denotes significant at the 1 percent level, ** significant at 5 percent level and $*$ significant at 10 percent level which reject of the null hypothesis on non-stationary. Critical value obtain from Fuller (1976) for constant but no time trend is $-3.45,-2.87$ and -2.57 for 1 percent, 5 percent and 10 percent significant level respectively, and the critical value for constant and time trend is $-3.98,-3.42$ and -3.13 for 1 percent, 5 percent and 10 percent significant level respectively.

Number in bracket is the optimum lagged based on Akaike Information Criterion (AIC).

${ }^{10}$ According to Blanchard and Quah (1989), Gali (1992), and Bjørnland and Leitemo (2009) the level and difference form variables can be combined in the VAR system as long as the system is stationary. An excellent survey about the issue of stationary systems, non-stationary I(1) systems, and a mixture of $\mathrm{I}(1)$ and $\mathrm{I}(0)$ variables in the SVAR model can be found in Levtchenkova et al. (1998).

${ }^{11}$ The full result of SVAR contemporaneous coefficient estimation is available upon request. 
effects of external shocks on domestic macroeconomics. The solid line represents the estimated responses; meanwhile the two dashed lines represent the confident bands or error bands. The error bands of the SIRF are derived from Hall's bootstrapping methodology, which has a 68 percent confidence interval with 300 being the number of bootstrap replications. ${ }^{12}$ Accumulated impulse-response functions will be discussed for the first difference variables responses, while the usual IRF will be used for the level form variable responses. By accumulating the responses of the first-difference variable on its structural shocks, we can interpret the impact of structural shocks on the level form of endogenous $(Y)$ variables.

\section{Foreign Shocks Effects on Domestic Variables}

Response of domestic monetary policy. Panel A in Appendix 1 shows the response of interest rates to the innovation in foreign shocks, and Panel B describes the accumulated response of the money supply to the innovation in foreign shocks. As can be seen in Appendix 1 (Panel A), the response of the interest rates to the innovation in world oil price growth is negative, decaying after 30 months. The accumulated response of the money supply has a positive effect to the innovation in world oil price growth. These findings indicate that the monetary authority's concern is the negative effects of world oil price shock on domestic output, and therefore implementing an easing monetary policy through a decrease in interest rates, and an increase in money supply. This strategy is crucial to offset the adverse supply shocks on economic activity through stimulating the aggregate demand.
Interest rate response is significantly positive to foreign income shocks with the highest response being 0.3 percentage points within 25 months. However, after 25 months the positive response of the interest rate begins to reduce and decays after 60 months. The money supply response is negative to foreign income shocks. For instance, an accumulated response of the money supply, in response to a one percent increase in foreign income growth is appropriately -0.6 percent after a 25 month period. One possible explanation is that the monetary authority has been concerned with stabilizing the domestic price level, since the expansion of foreign income has triggered an increase in domestic inflation due to an increase in external demand.

The domestic interest rate has responded positively to the FFR shocks, with the highest response being 0.15 percentage points change in 15 months. The money supply has negatively responded to the positive innovation in FFR. This finding indicates that the monetary authority is concerned about the capital outflow from the domestic country to the US due to the monetary tightening in the US. Therefore, to ensure that portfolio investment in Malaysia is competitive, the BNM has to respond by increasing the domestic interest rates.

Response of domestic macroeconomic variables. Appendix 2 in Panel A-Panel C describes the response of domestic macroeconomic variables to the innovation in foreign shocks. As depicted in Appendix 2 in Panel A, a positive innovation in world oil price growth leads to an increase in domestic output in within a two month period. However, after four months the positive innovation of the world oil price growth leads to a

\footnotetext{
${ }^{12}$ The SVAR model has been estimated by using J-Multi statistical software developed by Lutkepohl and Kratzig
} (2004). 
decline in domestic output. There is no significant effect of world oil price on domestic output after 12 months. The positive response of output within a two month period is reasonable given that Malaysia is a net oil exporting country. An increase in the world oil price has generated higher income for the petroleum industry, and subsequently leads to an increase in domestic output. However, after four months, output responds negatively to the world oil price because of the adverse supply shocks. For example, an increase in the world oil price will lead to an increase in firms' production costs, and subsequently the firms will respond by reducing their investment spending. Domestic inflation also positively responds to the positive shocks in the growth of world oil prices. For instance, the highest effect is recorded in a 5 month period, at which point every 1 percent increase in world oil prices growth leads to an increase in the inflation rate of 0.25 percent. However, after 5 months the response of inflation has gradually declined, and vanishes within 40 months.

The exchange rate responds positively and significantly to the positive shock in the world oil price growth, and the accumulated effect is approximately 0.6 percent in 60 months. In other words, an increase in the world oil price triggers an appreciation in the domestic currency relative to other currencies because Malaysian is a net exporter of oil. The stock market responds positively to the positive shock in the world oil price growth, but decays after 40 months.

Panel B in Appendix 2 plots the response of domestic macroeconomic variables to innovation in foreign income (US output). As can be seen, domestic output growth positively responds to the foreign demand shock. The positive response of domestic income is reasonable since most of the Malaysian ex- ports are concentrated in the US market. The effect of the US income shock to domestic inflation is negative within 20 months, whereas after 20 months domestic inflation has responded positively. This indicated that after 20 months, foreign income shocks can influence domestic inflation through an increased external demand, which is subsequently stimulating the aggregate demand.

A positive shock in the US income has caused the exchange rate to respond negatively within 25 months; however, after 25 months the response is positive. The positive response of exchange rate (appreciation in domestic currency) occurs because an increase in foreign income has stimulated domestic exports, and afterwards has increased the demand for domestic currency. Asset price has responded positively to the positive innovation in the foreign income, which is increased by 0.08 percent within a 60 months period.

Panel C in Appendix 2 shows the effect of foreign monetary shocks on domestic macroeconomic variables. As can be seen, the accumulated response of domestic output is positive within a 5 month period; however, the effect is relatively small. After 5 months, the accumulated response of domestic output is negative. For example, within a 20 month period; the accumulated response of domestic output has decreased by 0.4 percent in responding to a one percentage point increase in FFR. A possible explanation is that an increase in the foreign interest rate has contracted foreign economic activity, which afterwards decreased foreign demand, and subsequently contracted the domestic economy. Domestic inflation has responded negatively to positive innovation in FFR after 2 months, and decayed after 25 months. For example, in 10 months, domestic inflation has decreased by 0.1 percent in response 
to a one percentage point increase in foreign monetary policy.

The accumulated response of exchange rates to the innovation in FFR is positive. A possible reason is that the $\mathrm{BNM}$ has increased the domestic interest rates to offset the capital outflow to the foreign country. The accumulated response of the stock market to the FFR shocks is positive and relatively small in 5 months, which indicates that foreign monetary policy is not important in influencing the domestic stock market. However, after 7 months, the stock price has responded negatively with the positive innovation in FFR.

\section{Monetary Policy Effects on Domestic Variables}

Interest Rate Shocks. Appendix 3 in Panel A indicates the effect of the interest rate shock on domestic macroeconomic variables. As can be seen, domestic output growth has responded negatively to a positive shock in interest rates. For instance, the accumulated response of domestic output is -0.003 percent after 20 months, which is indicated that a one percentage point increase in interest rates (IBOR) leads to a contraction in domestic output of 0.3 percent. The negative response of domestic output to monetary policy tightening can be explained by standard economic theory, by which an increase in interest rates increases the firms' capital costs, while in turn the firms will respond by reducing their capacity of fixed investment. The response of inflation to monetary policy tightening is positive, which indicates the existence of a price puzzle. Barth and Ramey (2000) have provided an alternative explanation of the price puzzle, where they argued that monetary policy tightening operates on aggregate supply as well as aggregate demand. Specifically, an increase in interest rates raises the cost of holding inventories (cost channel of monetary policy). This negative supply effect raises domestic inflation and lowers output. Money supply has responded negatively to a positive shock in interest rates, where the accumulated effect is -0.2 percent after 20 months.

The exchange rate responds positively to the positive innovation in interest rates. For instance, after 10 months, the accumulated response of the nominal exchange rate is 0.012 , which indicates that a one percentage point increase in interest rates leads to an appreciation in the nominal exchange rate by 1.2 percent. A possible reason is that an increase in interest rates has stimulated the capital inflows to the domestic country, and subsequently increased the demand for the domestic currency, and fuels the exchange rate appreciation. The stock market also responds positively within 5 months, however after 5 months, stock price response is negative to the innovation in interest rates. One possible reason is that an increase in interest rates has contracted economic activity and dividend payments, which in turn decreased the asset price.

Money Supply Shocks. Appendix 3 in Panel $B$ plots the money supply (narrow money M1) impulses on domestic macroeconomic variables. As can be seen, in one month, the accumulated response of domestic output is negative in response to positive innovation in money supply growth. However, after one month, there is a positive cumulative effect of the shocks in money supply growth on domestic output. For instance, the highest cumulative effect is shown in 3 months, where one percent increase in money supply growth leads to an increase in domestic output by approximately 0.3 percent. However, after five months, the positive accumulated response of domestic output has decreased. 
Specifically, after 15 months, the accumulated response of domestic output is 0.1 percent. This finding indicates that the money supply plays an important role in stimulating domestic output growth. The response of inflation on money supply growth shows a hump-shape pattern, and returns to the equilibrium path after 15 months.

Interest rates respond positively to the innovation in money supply growth, which indicates the existence of a liquidity puzzle. Some empirical studies, for example Reichenstein (1987), and Leeper and Gordon (1991) have supported the existence of the liquidity puzzle. In addition, the positive effect of interest rates gradually decreases and vanishes after 30 months. The effect of money on the exchange rate is not statistically significant. In comparison, the stock market has a positive response to money supply shocks, which indicates that an expansionary monetary policy has stimulated the asset price to increase.

\section{Robustness Checking ${ }^{13}$}

For robustness checking, several alternative procedures have been considered in this study; (i) estimating the recursive SVAR model; (ii) alternative contemporaneous structural identification schemes; (iii) model with money demand; and (iv) model without money. Overall, the structural IRF are robust with the baseline restriction.

\section{Summary and Conclusions}

The focal point of this study is to examine the role of monetary policy during interest rates targeting in a small-open economy (i.e. Malaysia) by using an open-economy SVAR study. Specifically, this study investigates the effect of external shock, namely the world oil price and the US international transmission (US income and US monetary policy) to domestic monetary policy and macroeconomic fluctuations. In addition, this study examines the effectiveness of domestic monetary policy in stimulating the macroeconomic variables (output and inflation).

Several major conclusions can be drawn from the empirical findings. First, the world oil price shock has generated a significant effect in influencing domestic monetary policy implementation and macroeconomic variables in the Malaysian economy. Second, the US transmission in terms of the US income and the US monetary policy shocks have also played a prominent role in influencing domestic monetary policy and macroeconomic fluctuations. Third, domestic monetary policy, either money supply or interest rates have played a significant role in stabilizing economic activity (output and inflation).

These findings have several implications for domestic monetary policy implementation. First, since the foreign shocks can influence domestic macroeconomic fluctuations, the monetary authority (in particular, the BNM) has to make an accurate assessment about the external events by monitoring international conditions in implementing monetary policy. This is very important for minimizing the negative effect of the foreign shocks on the macroeconomic fluctuations through proactive monetary policy measures.

Second, there is a relevant role for monetary policy instruments (money supply and interest rates) in stimulating macroeconomic

\footnotetext{
${ }^{13}$ I do not report the full result of robustness checking to save space. However, the full results are available upon request.
} 
variables, which suggests that monetary policy can be used as a stabilization policy.

Third, during the interest rate targeting regime, domestic monetary policy has positively responded to the foreign monetary policy shocks. It seems that the BNM has to follow the US monetary policy. This strategy is crucial under perfect capital mobility to maintain the competitiveness of the domestic financial assets, and it can stabilize the domestic currency. As noted by Umizaki (2007), the BNM not only has to consider the domestic factors such as inflation rates and output but also foreign variables, particularly foreign monetary policy and exchange rates, in designing an appropriate monetary policy rule.
Fourth, since domestic output has responded negatively to interest rates, the $\mathrm{BNM}$ has a greater opportunity to stimulate economic activity by controlling the interbank overnight interest rates. Finally, the monetary policy also plays an important role in stabilizing economic activity via the exchange rate and stock market effects. For example, the central bank can stimulate the export sector by implementing an easing of monetary policy (either by an increase in money supply or decrease in interest rates). This strategy will depreciate domestic currency, and subsequently stimulate external demand and economic activity.

\section{References}

Amisano, G., and C. Giannini. 1996. Topics in Structural VAR Econometrics. Berlin: Springer.

Azali, M., and K. Matthews. 1999. Money-Income and credit-income relationships during the pre-and the post-liberalization periods: Evidence from Malaysia. Applied Economics 31: 1161-1170.

Barth, M. J., and V. A. Ramey. 2000. The cost channel of monetary transmission. NBER Working Paper Series. Cambridge: National Bureau of Economic Research.

Bernanke, B. S. 1986. Alternative explanations of the money-income correlation. Carnegie-Rochester Conference Series on Public Policy 25: 49-100.

Bernanke, B. S., and A. S. Blinder. 1992. The federal funds rate and the channel of monetary transmission. The American Economic Review 82: 901-921.

Bernanke, B. S., M. Gertler, and M. Watson. 1997. Systematic monetary policy and the effects of oil shocks. Brookings Papers on Economic Activity 1: 91-157.

Bernanke, B. S., and I. Mihov. 1998. Measuring monetary policy. The Quarterly Journal of Economics 113: 869-902.

Bjørnland, H. C., and K. Leitemo. 2009. Identifying the interdependence between US monetary policy and the stock market. Journal of Monetary Economics 56: 275-282.

Blanchard, O., and D. Quah. 1989. The dynamic effects of aggregate demand and supply disturbances. American Economic Review 79: 655-673.

Brischetto, A., and G. Voss. 1999. A structural vector auto regression model of monetary policy in Australia. Research Discussion Paper. Reserve Bank of Australia. 
Bucle, R. A., K. Kim, H. Kirkham, N. McLellan, and J. Sharma. 2007. A Structural VAR business cycle model for a volatile small open economy. Economic Modeling 24: 990-1017.

Cushman, D. O., T. Zha. 1997. Identifying monetary policy in a small open economy under flexible exchange rates. Journal of Monetary Economics 39: 433-448.

Domac, I. 1999. The Distributional Consequences of Monetary Policy: Evidence from Malaysia. Policy Research Working Paper the World Bank. East Asia and Pacific Region.

Dungey, M., and A. Pagan. 2000. A Structural VAR model of the Australian economy. The Economic Record 76: $321-342$.

Fuller, W. A. 1976. Introduction to Statistical Time Series. New York: John Wiley.

Gali, J. 1992. How well does the IS-LM model fit postwar U.S data? . The Quarterly Journal of Economics 107: 709-738.

Hamilton, J. 1996. This is what happened to the oil price macro economy relationship. Journal of Monetary Economics 38: 215-220.

Handa, J. 2009. Monetary Economics. London and New York: Routledge, Taylor \& Francis Group.

Ibrahim, M. 2005. Sectoral effect of monetary policy: Evidence from Malaysia. Asian Economic Journal 19: 83-102.

Jensen, G. R., and J. M. Mercer. 2002. Monetary policy and the cross-section of expected stock return. The Journal of Financial Research XXV: 125-139.

Kim, S., and N. Roubini. 2000. Exchange rate anomalies in the industrial countries: A solution with a structural VAR approach. Journal of Monetary Economics 45: 561-586.

Leeper, E. M., and D. B. Gordon. 1991. In search of the liquidity effect. Journal of Monetary Economics 29: 341-369.

Levtchenkova, S., A. R. Pagan, and J. C. Robertson. 1998. Shocking stories. Journal of Economic Survey 12: 507-532.

Levy J., and I. Halikias. 1997. Aspects of monetary transmission mechanism under exchange rate targeting: the case of France. IMF Working Paper Series.

Ludvigson, S., C. Steindel, and M. Lettau. 2002. Monetary policy transmission through the consumptionwealth channel. FRBNY Economic Policy Review: 117-133.

Lutkepohl, H., And M. Kratzig (eds.) 2004. Applied Time Series Econometrics. New York: Cambridge University Press.

Parrado, E. 2001. Effects of foreign and domestic monetary policy in a small open economy: The case of Chile. Working papers (108). Central Bank of Chile.

Ramaswamy, R., and T. Sloek. 1997. The real effects of monetary policy in the European Union: What are the differences? IMF Working Paper (97/160).

Ramey, V. A. 1993. How important is the credit channel in the transmission of monetary policy? NBER Working Paper Series. Massachusetts Avenue, Cambridge.

Reichenstein, W. 1987. The impact of money on short-term interest rates. Economic Inquiry 25: 67-82.

Sellin, P. 2001. Monetary policy and the stock market: theory and empirical evidence. Journal of Economic Surveys 15: 491-541. 
Gadjah Mada International Journal of Business - Jamuary-April, Vol. 16, No. 1, 2014

Sim, C. A, and T. Zha. 2005. Does monetary policy generate recession? Macroeconomic Dynamics 14: 1-42.

Tang, H. C. 2006. The relative important of monetary policy transmission channels in Malaysia. CAMA Working Paper Series. The Australian National University.

Umizaki, S. 2007. Monetary policy in a small open economy: The case of Malaysia. The Developing Economics XLV (4): 437-464.

Zaidi, M. A. S., and L. A. Fisher. 2010. Monetary policy and foreign shocks: A SVAR analysis for Malaysia. Korea and the World Economy 1 (3): 527-550. 
Appendix 1. Structural Impulse-Response Function: The Effect of Foreign Shocks on Monetary Policy Variables
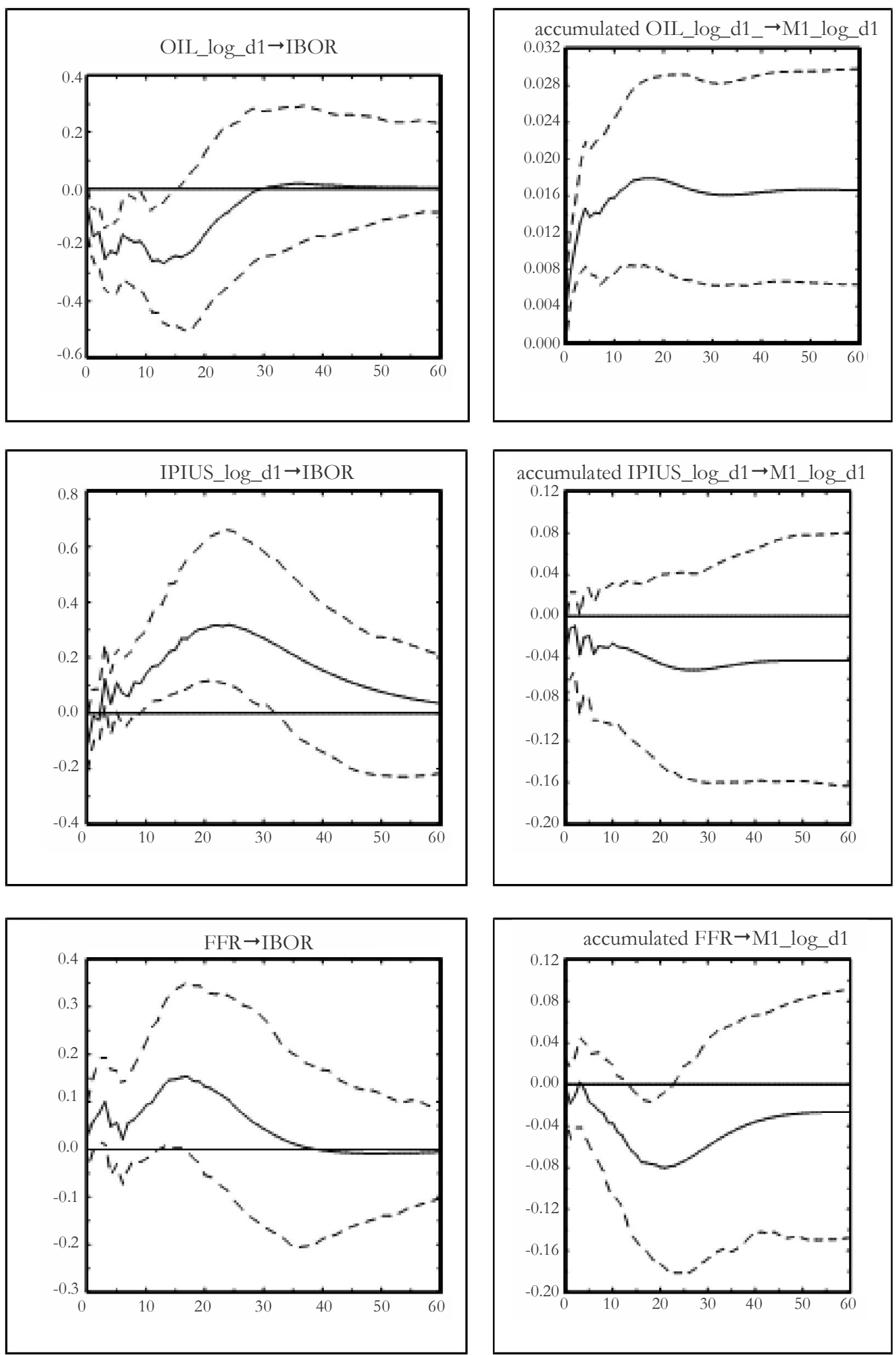
Gadjah Mada International Journal of Business - Jamuary-April, Vol. 16,No. 1, 2014

Appendix 2. Structural Impulse-Response Function: The Effect of Foreign Shocks on Macroeconomic
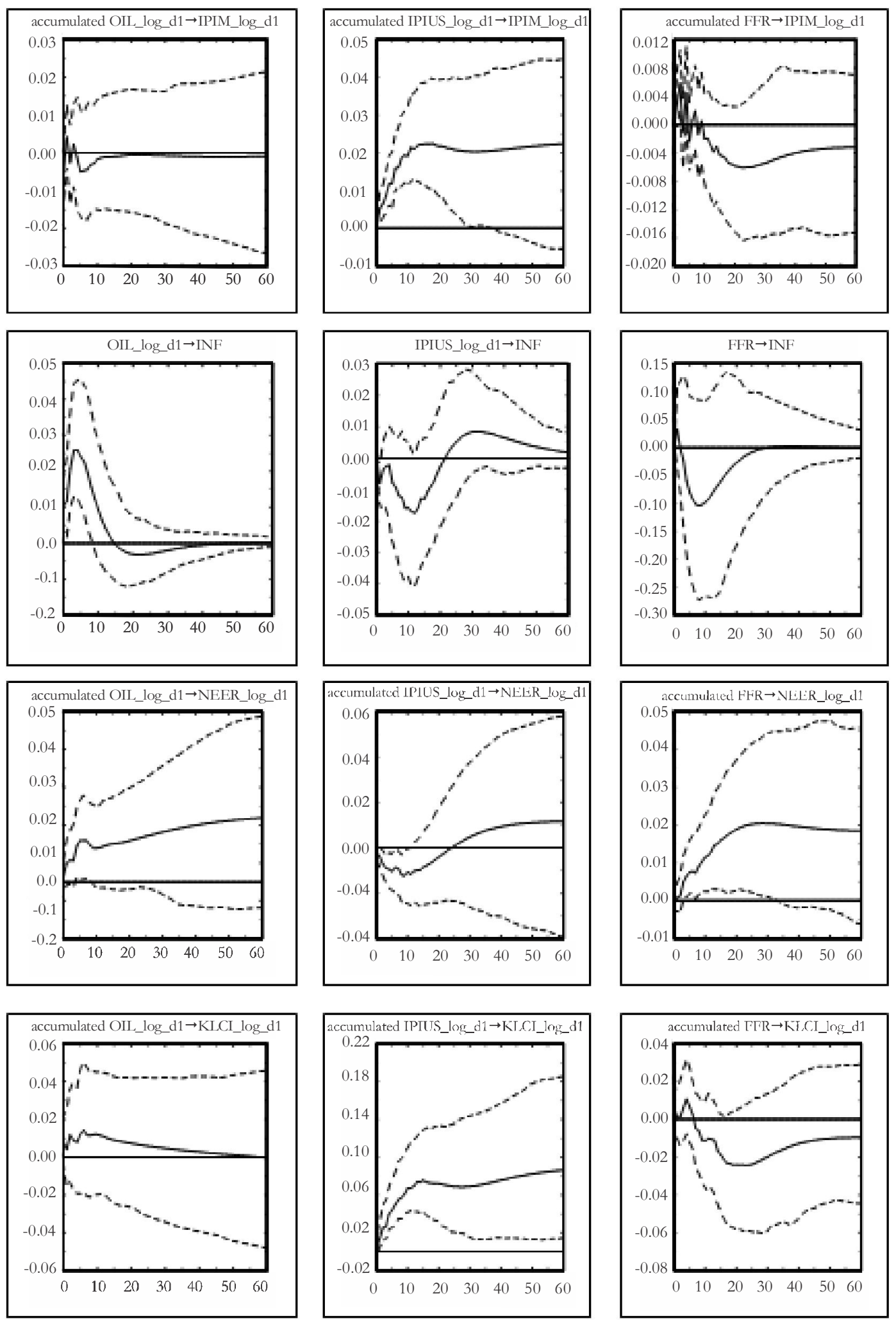
Karimand Karim

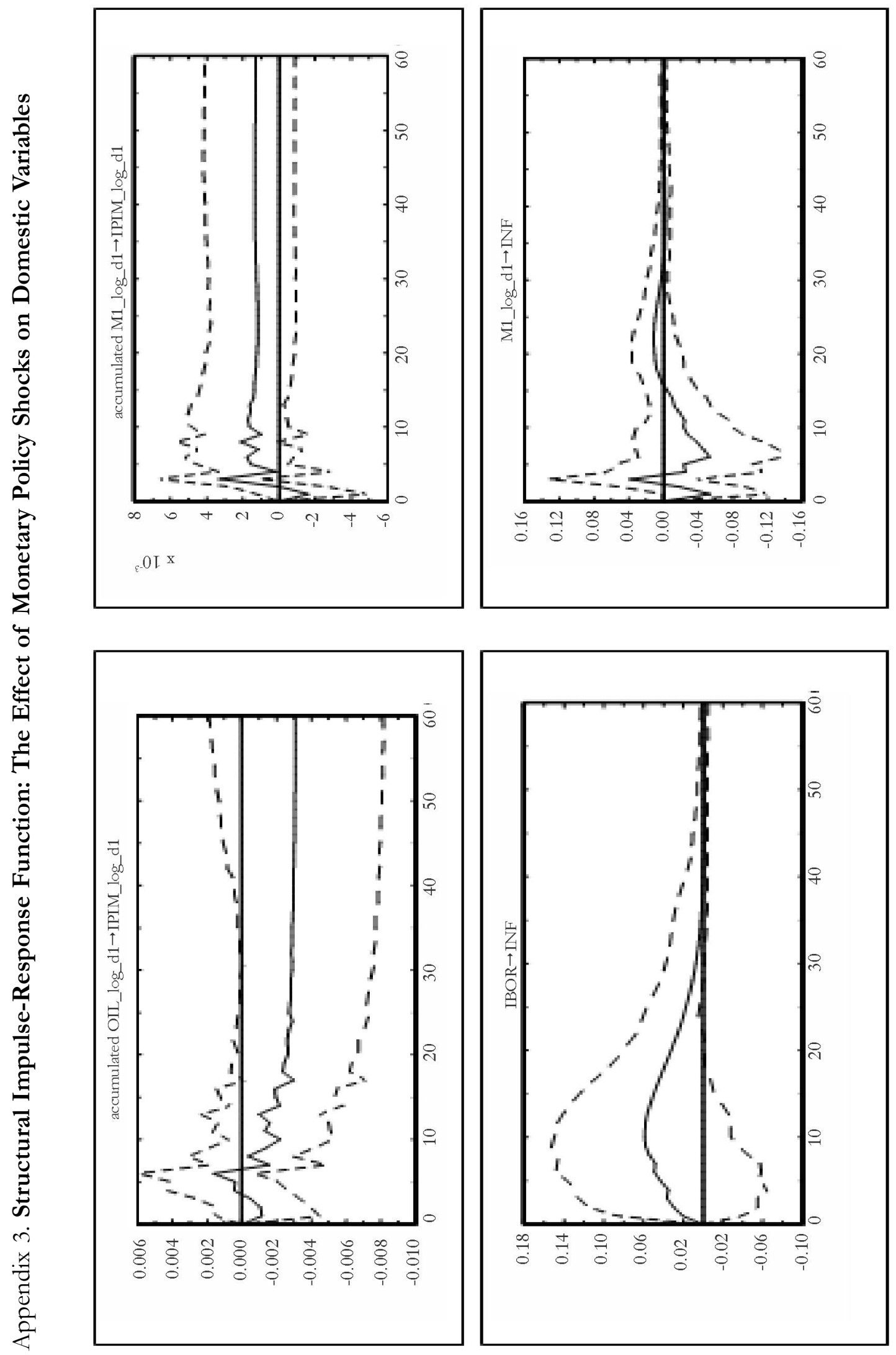


Gadjah Mada International Journal of Business - Jamuary-April, Vol. 16, No. 1, 2014
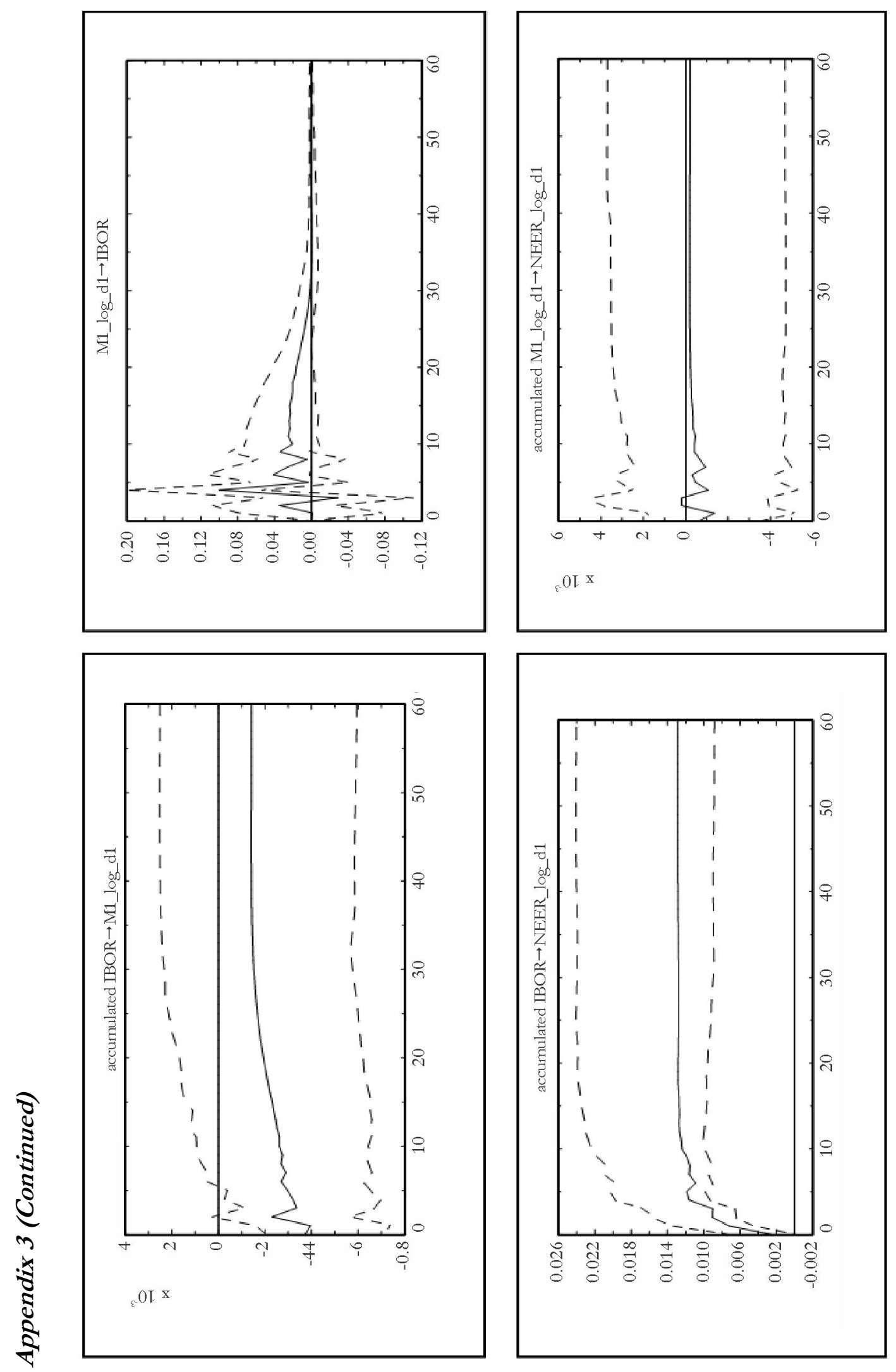
Karimand Karim
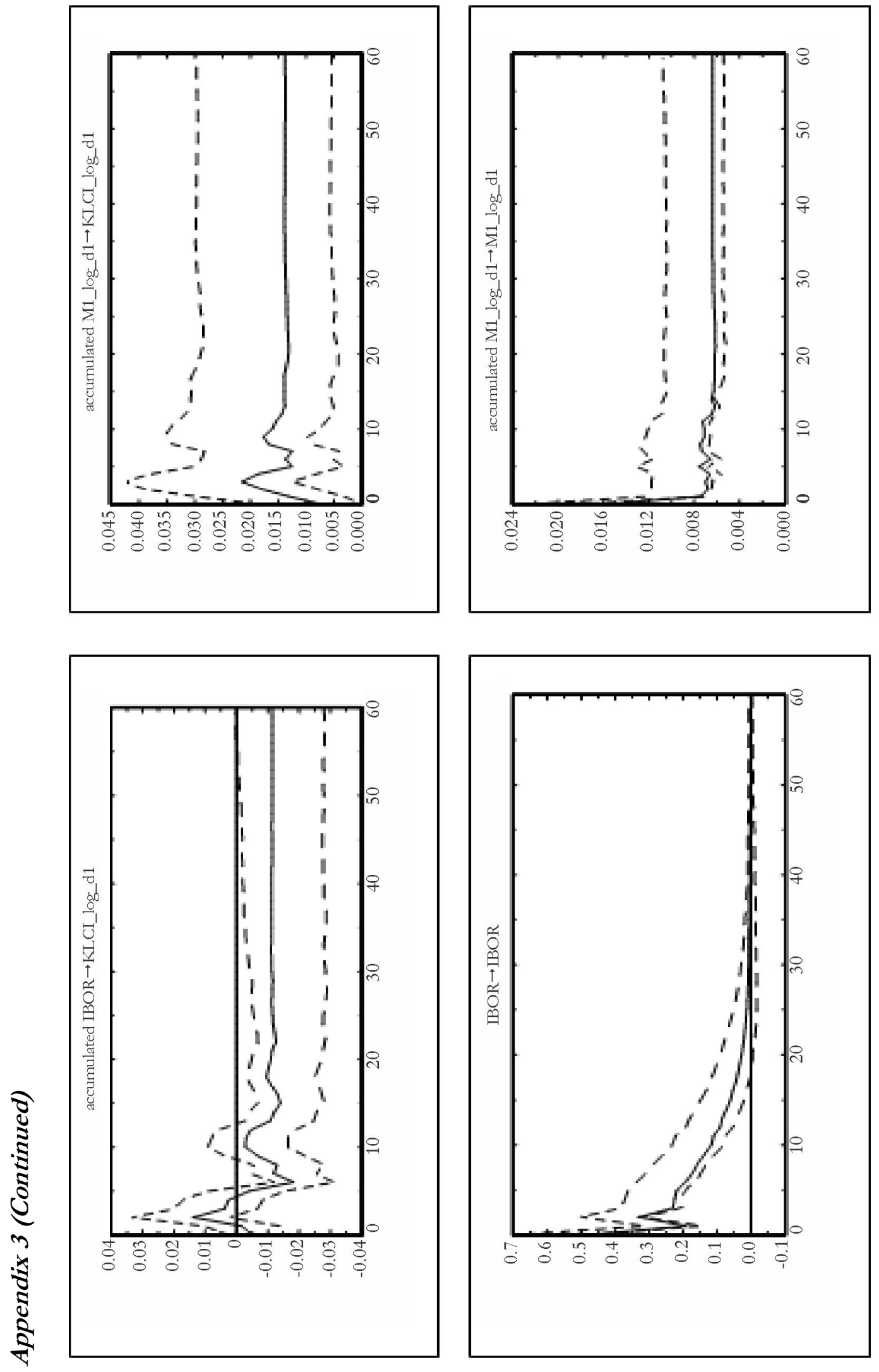
